\title{
Optimum Management of COVID-19 in the Geriatric Population: The Need for a Comprehensive Assessment
}

\author{
Birkan Ilhan, ${ }^{1}$ Yuksel Altuntas ${ }^{2}$ \\ 'Department of Internal Medicine, Division of Geriatrics, University of Health Sciences Turkey, Sisli Hamidiye Etfal Teaching and Resarch \\ Hospital, Istanbul, Turkey \\ 2Department of Internal Medicine, Division of Endocrinology Metabolism Diabetes, University of Health Sciences Turkey, Sisli Hamidiye \\ Etfal Teaching and Resarch Hospital, Istanbul, Turkey
}

Please cite this article as "Ilhan B, Altuntas Y. Optimum Management of COVID-19 in the Geriatric Population: The Need for a Comprehensive Assessment. Med Bull Sisli Etfal Hosp 2020;54(3):388-389".

C OVID-19 was declared as a pandemic and global emergency by the World Health Organization (WHO) in March 2020. Mortality rates have varied considerably among countries. According to the current data of WHO, the mortality rate in Turkey appears to be lower compared to Italy (2.4\% vs. $13 \cdot 5 \%)$. One of the reasons may be a lower rate of the geriatric population compared to Italy (9.1\% vs. $22 \cdot 8 \%$ ) and the second reason may be the earlier timing of lockdown for people over 65 years in Turkey. Data indicate that COVID-19 is a certain risk for older adults. In general, the geriatric population is a group individulas are with multiple diseases. Therefore, clinicians are faced with a more complicated picture of not only COVID-19 but also accompanying situations in older adults. Accordingly, it is essential to carry out a comprehensive assessment and manage accompanying problems in an ideal way besides COVID-19. Geriatric syndromes are the most important accompanying conditions, such as malnutrition, delirium, dementia, falls, and frailty, which are highly prevalent, multifactorial, and associated with substantial morbidity and poor outcomes in all clinical settings. Although COVID-19 is known to be presented with fever and symptoms of the respiratory tract, it can only be presented with a new-onset geriatric syndrome as recent studies reported. ${ }^{[1-3]} \mathrm{It}$ is called 'atypical presentation, which is very often in older adults in general practice. Common presentations include altered mental state (delirium), failure to eat and drink (malnutrition), failure to develop fever, functional decline, and falls in general aspects. Thus increased attention and comprehensive assessment are required to find out underlying disease, including COVID-19.

In critical patients, especially prolonged disease, malnutrition, excessive muscle protein loss, and muscle atrophy may occur in the catabolic process. Atrophy of the diaphragmatic muscle may lead to difficulty in weaning in patients with mechanical ventilator. ${ }^{[4]}$ Not only critical conditions but also 'aging' itself is a strong predictor for malnutrition. Accordingly, the European Society for Clinical Nutrition and Metabolism reported an expert statement and practical guidance for nutritional management for individuals with COVID-19 in March 2020.[5] This report states the negative impacts of malnutrition on patient survival.

Address for correspondence: Birkan Ilhan, MD. Saglik Bilimleri Universitesi, Sisli Hamidiye Etfal Egitim ve Arastirma Hastanesi, Ic Hastaliklari Anabilim Dali, Geriatri Bolumu, Istanbul, Turkey

Phone: +90 2123735000 E-mail: birkanilhan@hotmail.com

Submitted Date: August 28, 2020 Accepted Date: September 03, 2020 Available Online Date: September 06, 2020

${ }^{\circ}$ Copyright 2020 by The Medical Bulletin of Sisli Etfal Hospital - Available online at www.sislietfaltip.org

OPEN ACCESS This is an open access article under the CC BY-NC license (http://creativecommons.org/licenses/by-nc/4.0/). 
Thus, diagnosis and treatment of malnutrition should be considered in the management of COVID-19 to improve both short- and long-term prognosis. Hence, older adults should be assessed for malnutrition in all clinical settings.

Polypharmacy and adverse drug effects are common in both community-dwelling older adults and nursing home residents. Hydroxychloroquine and azithromycin have been commonly used for COVID-19 treatment and have a potential risk of QT prolongation. Combination with other risky drugs, such as quetiapine, haloperidol, hydroxyzine, alfuzosin, amitriptyline, donepezil and piperacillin/tazobactam, may lead to severe QT prolongation. ${ }^{[6]}$ Therefore, every single medication should be reviewed carefully concerning potential drug interactions and inappropriate use in older patients.

Regarding delirium and COVID-19, studies have reported that $20-30 \%$ of patients may present delirium or mental changes while applying to the hospital or during their hospitalization and this rate can be up to $60-70 \%$ in cases of severe illness in all age groups. ${ }^{[7,8]} \mathrm{A}$ person with dementia may easily develop delirium when hospitalized in an isolated room alone, taking care by staff with personnel-protective-equipment who looks like an unknown person for him/her. Also, depression and anxiety may be other missing precipitating factors in addition to well-known metabolic derangements. It is essential that a caregiver or family member to accompany the isolated older patient, particularly those with cognitive impairment. This can be critical to combat fear and anxiety and reach effective non-pharmacological approaches for the prevention and management of delirium. Delirium is considered the 'vital sign' in older adults and should be screened on admission and during hospitalization. ${ }^{[9]}$

The longer period of hospitalization, severe disease, dyspnea, muscle loss and caregiver problems may lead to immobilization in hospitalized older adults with COVID-19. The struggle against immobilization should start as early as possible.

Diabetes Mellitus (DM) is one of the common chronic conditions among older adults and has been pronounced as a risk factor for COVID-19. ${ }^{[10]}$ Clinicians should manage DM carefully in older adults with COVID-19. Older DM patients with COVID-19 have an increased risk for dehydration and lactic acidosis. Metformin and Sodium-glucose-co-transporter-2 inhibitors are very risky drugs. Both drugs should be discontinued in especially frail and malnourished older adults to reduce the risk of acute metabolic decompensation. ${ }^{[10]}$ Thiazolidinediones are also inappropriate drugs in patients with heart failure, which is one of the common comorbidities in older patients with COVID-19. Dipeptidyl- peptidase-4 inhibitors are generally well-tolerated and can be continued. Insulin may be adjusted therapy if appropriate to reach therapeutic goals. ${ }^{[10]}$

By identifying the aforementioned age-related factors and vulnerabilities, critical care problems in older patients can be anticipated and managed.

\section{Disclosures}

Peer-review: Externally peer-reviewed.

Conflict of Interest: None declared.

Authorship Contributions: Concept - Y.A.; Design - B.I.; Supervision - Y.A.; Materials - B.I.; Data collection \&/or processing - B.I.; Analysis and/or interpretation - B.I.; Literature search - B.I.; Writing - B.I.; Critical review - Y.A.

\section{References}

1. Tay HS, Harwood R. Atypical presentation of COVID-19 in a frail older person. Age Ageing 2020;49:523-4. [CrossRef]

2. Alkeridy WA, Almaghlouth I, Alrashed R, Alayed K, Binkhamis $\mathrm{K}$, Alsharidi A, et al. A Unique Presentation of Delirium in a $\mathrm{Pa}$ tient with Otherwise Asymptomatic COVID-19. J Am Geriatr Soc 2020;68:1382-4. [CrossRef]

3. Isaia G, Marinello R, Tibaldi V, Tamone C, Bo M. Atypical Presentation of Covid-19 in an Older Adult With Severe Alzheimer Disease. Am J Geriatr Psychiatry 2020;28:790-1. [CrossRef]

4. Puthucheary ZA, Rawal J, McPhail M, Connolly B, Ratnayake G, Chan $P$, et al. Acute skeletal muscle wasting in critical illness [published correction appears in JAMA 2014;311:625. Padhke, Rahul [corrected to Phadke, Rahul]]. JAMA 2013;310:1591-600. [CrossRef]

5. Barazzoni R, Bischoff SC, Breda J, Wickramasinghe K, Krznaric Z, Nitzan D, et al; endorsed by the ESPEN Council. ESPEN expert statements and practical guidance for nutritional management of individuals with SARS-CoV-2 infection. Clin Nutr 2020;39:16318. [CrossRef]

6. Back D, Marzolini C, Hodge C, Marra F, Boyle A, Gibbons S, et al. COVID-19 treatment in patients with comorbidities: Awareness of drug-drug interactions. Br J Clin Pharmacol 2020 May 8 [Epub ahead of print], doi: 10.1111/bcp.14358. [CrossRef]

7. Mao L, Jin H, Wang M, Hu Y, Chen S, He Q, et al. Neurologic Manifestations of Hospitalized Patients With Coronavirus Disease 2019 in Wuhan, China. JAMA Neurol 2020;77:1-9. [CrossRef]

8. Helms J, Kremer S, Merdji H, Clere-Jehl R, Schenck M, Kummerlen $\mathrm{C}$, et al. Neurologic Features in Severe SARS-CoV-2 Infection. N Engl J Med 2020;382:2268-70. [CrossRef]

9. O'Hanlon S, Inouye SK. Delirium: a missing piece in the COVID-19 pandemic puzzle. Age Ageing 2020;49:497-8. [CrossRef]

10. Bornstein SR, Rubino F, Khunti K, Mingrone G, Hopkins D, Birkenfeld $A L$, et al. Practical recommendations for the management of diabetes in patients with COVID-19. Lancet Diabetes Endocrinol 2020;8:546-50. [CrossRef] 